\title{
Case study of farmer's problems crop production, dairy and nutrition through Participatory Rural Appraisal (PRA)
}

\author{
Shivam Gour and H.R. Jatav
}

\begin{abstract}
This research study was carried out from July 2016 to October 2019 in villege Salakhedi during our READY Programme. This study is part READY (Rural Entrepreneurship Awareness Development Yojana) that applied an integrated frame work for combined crop production, nutritional, food safety analysis in Ujjain Region. Here, The objective of the study was toanalyze the use of participatory rural appraisals (PRAs) with producers and consumers to investigate seasonality, constraints and opportunities in crop production, milk production.The PRAs allowed identifying seasonal crops and milk production and consumption.A wide range of production constraints were described by producers including insufficient technical knowledge, uncertainty in climatic conditions, poor package practices, poor quality breeds, cattle diseases, lack of capital, feed, water and reliable markets. While food and milk availability had a strong inûuenceon consumption. The main purpose are to get ourselves exposed in practicing the different PRA tools and to understand the scenario of the village and people's perception. Also, this research gives us hands-on experience of the Participatory Rural Appraisal activities.
\end{abstract}

KEY WORDS : PRA(Participatory rural appraisal), Crop production, Dairy, Nutrition, READY(Rural Entrepreneurship Awareness Development Yojana)

HOW TO CITE THIS PAPER : Gour, Shivam and Jatav, H.R. (2019). Case study of farmer's problems crop production, dairy and nutrition through Participatory Rural Appraisal (PRA). Res. J. Animal Hus. \& Dairy Sci., 10(2) : 48-56 : DOI: 10.15740/HAS/RJAHDS/ 10.2/48-56. Copyright@ 2019: Hind Agri-Horticultural Society. 